\title{
THE CHARACTERS AND MEANING OF THIRD PLACE IN HISTORICAL URBAN SPACE OF IRAN
}

Received August 24th 2016 | Accepted August 22nd 2017 | Available online December 15th 2017

DOI: 10.18860/jia.v4i4.3661

Ahad Nejad Ebrahimi

Assistant Professor of Architecture in Faculty of Architecture \& Urbanism.

Tabriz Islamic Art University, Tabriz, Iran.

Corresponding Author:

AhadEbrahimi@Tabrizlau.ac.ir

\section{Minou Gharehbaglou}

Associated Professor of Architecture in Faculty of Architecture \& Urbanism.

Tabriz Islamic Art University, Tabriz, Iran.

m.gharehbaglou@tabriziau.ac.ir

\section{Amir Hosein Farshchian}

Ph.D. Student of Islamic Architecture in Faculty of Architecture \& Urbanism.

Tabriz Islamic Art University, Tabriz, Iran.

AmirHoseinFarshchian@Tabrizlau. ac. ir

\begin{abstract}
Third place is the interface between work and life and due to the direct connection with urban development. It is a valuable space for attending the community in which one attends voluntarily, informally, and regularly or irregularly. There are such places in urban areas of Iran where people are able to attend in order to do social and religious activities and it seems like that the architectural nature of such spaces has some similarities and differences with the definition of third place. The research question is, "what are the features of third place in pre-modern cities of Iran and are the features in accordance with the definition of third place?". This is a developmental research conducted via the interpretive-historical method. The findings indicate that third place is commonplace in Iranian Cities and some architecture types like public, religious and residential spaces have fundamental similarities with the definitions of third place In Iranian Historical cities, but there are also some differences due to culture, religion, and climate in each region. Third places have widely exited in most applications and religious relations, rituals, and beliefs which demonstrate that brotherhood and communion have significantly influenced the formation of this place. The main issue in this regard is the firm presence of religion and strong ethnocultural ties which have affected the constituents of third place as components like the constant presence of water, creation of special, simple, and defined spaces, respect to adults and providing special furniture for them, and focusing on geometry and aesthetic proportions.
\end{abstract}

\section{KEYWORDS:}

Third place; urban space; architecture; Iran

\section{INTRODUCTION}

In addition to providing welfare, commercial and residential services, the cities also make social and cultural relations come true. Accordingly, the body of the city should be tailored to cultural-social needs to provide the possibility of a favorite social life, man's relationship with the community will require him a place to exchange thoughts and ideas.

Public places in cities contribute to the satisfaction of such needs under the title of social interaction. These places in non-Iranian collective spaces are referred to as third place. The quality of third place is one of the main assessment criteria of the cities abilities in responding to the social needs of the citizens.

According to diagram 1, the features of such spaces based on the location depend on various factors that result from the effects of the region. Therefore, understanding the effective factors in each area, like culture and religion, can contribute to recognizing and reasoning the features of such spaces and can reveal the similarities and differences between them.

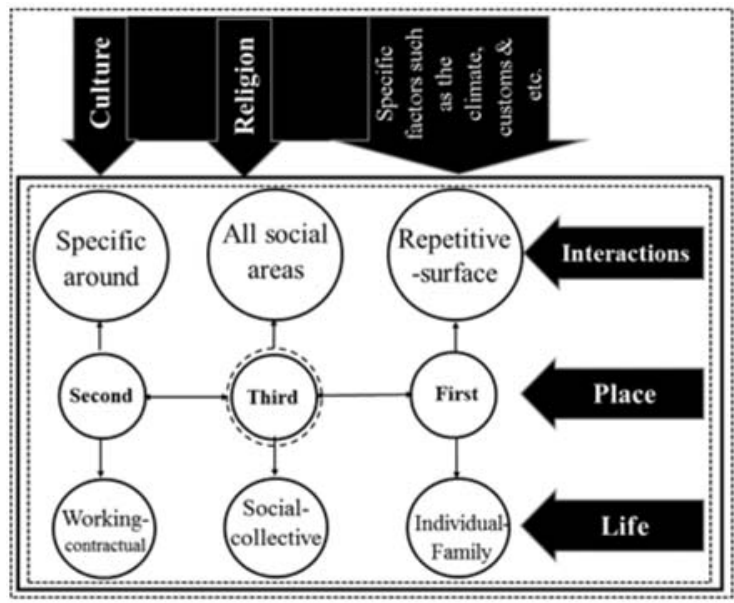

Diagram 1. Type of social relations in the first, second, and third places and its favorability in the third place, source: authors, according to Oldenburg, 2000. 


\section{METHODS}

The foundation of the research is based on developmental studies via interpretive, historical method and along with the analysis of urban elements and historic architecture of cities especially in Historical Persian Houses and Bazaars in Iran [1]. The hypothesis is stated as:

"Public places in pre-modern urban space have been in accordance with culture and identity and it seems like that the architectural nature of these spaces has some similarities and differences with the third place". This paper tries to answer the following question, "what are the features of third place in pre-modern cities of Iran and are the features in accordance with the definition of third place?". The needed data are obtained through the field surveys and analysis of documents and deeds.

\section{DISCUSSION}

So far, studies and surveys have generally progressed towards the recognition of third place as the public space model and in most versions, the goal is to create this space and to change the usage for converting a useless place to this space. Conducted research in Iran is devoted to the definition of nonIranian patterns and the placement of such spaces in the urban development system of Iran Cities. In this writing, the main difference is the review of the issue, the type of viewpoint governing this space in the past history of urban development in Iran and the definition by which the third place in non-Iranian patterns can be simulated. The main findings of the research are aimed at the recognition of the type of the relationship between this space and urban places as well as the difference in the architecture due to the strong influence of culture and religion that are rooted in customs and traditions and prominent presence of religion.

\section{MEANING OF THIRD PLACE}

First place is the place where people spend most of their time and due to being in touch with certain people frequently the interactions are limited and often repeated-centered. In the second place due to special areas of work, the occurred interactions have special directions and are around the work issues. Social relations that create vitality and freshness in people are realized in the third place. Oldenburg made a more general definition of third place in 1932 as "the space between the first and second places that the citizens are in touch with for any reason and its improvement leads to the social growth of people" and also as "the host of regular, irregular, voluntary, informal, and fortunately unpredicted gatherings of people out of the territory of the first and second places" [2]. Traditional applications such as markets, mosques, shrines, central neighborhoods, public baths and other elements of traditional-historical urban architectures as well as the current applications of shops, coffeehouses, bus stations and other urban applications that are an area for social interactions play such a role. During the years when the first sparks of attention to the third place were lighted, this assumption was considered as an appropriate approach in relation to urban architecture and designing by the experts in science and technology and successful patterns such as urban space design were carried out in an area of Seattle, Washington. The presented figures and statistics revealed the increase of citizens' satisfaction and the ascending growth of social interactions. What is remembered of a person's life from being in the barber's shop in the childhood to attending the bookstore in the middle age remains in one's mind as a good place? "Third place is a general need for the civil society and its activities in order to create a sense of place". During the years when the first sparks of attention to the third place were lighted, "according to environmental psychologists and architects, the third place is the most important place for favorite social interactions and is able to satisfy social needs of the citizens". When a person is in environments with various spaces and other people's figures, "the perception sense of human gets involved in understanding the environment and knowing the people" [3]. During this period, he has a special and different feeling and considers himself away from his work problems and relations. This matter is somewhat undervalued in terms of social relations in the first and second places where the faces are repetitive and conventional.

\section{THE CHARAC TER OF THIRD PLACE}

Third place characteristics should have "scopes and functions by which the citizens experience being stopped in a place and spending time in that space". According to diagram 2, the most important factors involved in designing the third place are addressing the issues such space architecture, urban architecture, and social issues".

\section{- Urban Architecture}

Appropriate location attention and management with regard to population assessment and space audience identification, creating diverse and convenient access so that the citizens can be easily spotted and the estimate of coverage that a place can provide in relation to its own area.

\section{- Space Architecture}

Creating and embedding elements of spatial strength, spatial diversity and rhythm in place and using aesthetic principles such as the presence of nature and art effects in different fields.

\section{- Social Issues}

A review of the requirements that must be responded in a place through which the space audience ensure being in the space, the ability of the place to attract all socio-economic classes with any favorite cultural-ethnic diversity and creating environmental vitality due to the constant presence of individuals in the space as well as the use of any issues that can illustrate the type of ecology and identity of the area and people and making them feel they belong to that place. 
In fact, by being present in the third place, individuals must face a kind of feeling as "a home away from home". Such feelings can include environmental curiosity, space spatial shelter, expression of friendship, stating conversation with others, feeling a sense of ownership of a limited place, and other perceptional points.

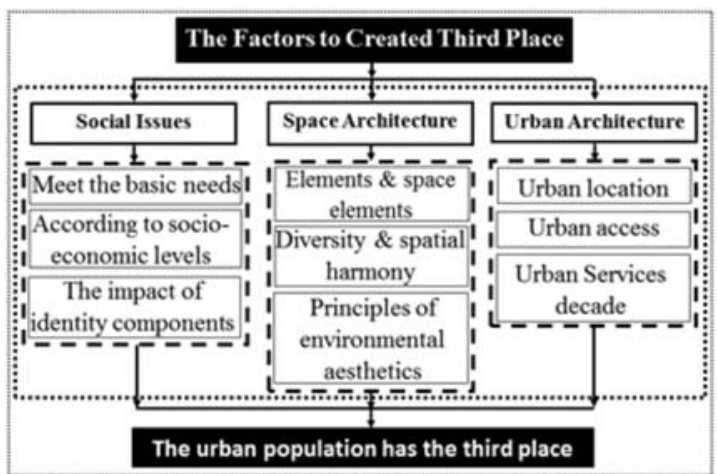

Diagram 2. Third place creating factors and sub-components, source: authors according to Oldenburg, 2000 [2]

\section{"THIRD PLACE" LOCATION}

The third place that can attract people to attend architectural space should have the architectural components of a good place in designing and its purpose and application should be identified. Christopher Peterson, 2013, along with a group of social science and urban exerts and with regard to the definition of third place by Oldenburg and according to the results of conducted studies, expressed the objectives and application of this space within seven criteria as [4]:

1. People should not attend this place to spend their extra time, but they should feel a kind of need in their life that is satisfied by attending this place. This process might be as a pastime in the early stages of citizen's attendance, but in the next steps, the need to the place will lead them to that place.

2. The sense of place ownership should be similar for all the citizens even the state authorities covering the place. All should feel they are guests in the space like other people and when the place needs to be handled all should feel as hosts. In fact, the place belongs to all and nobody has the ownership right to a part of it.

3. The most important function of this space should be creating the sparks of dialogue between citizens which is followed by environmental awareness and social intelligence enhancement of the citizens.

4. All people should have access to the place in the easiest way with place varying from crowded to uncrowded parts.

5. With regard to its placement in a certain area and the type of its culture and identity, the place should have special rules so that the other citizens are not disrespected.

6. The construction of space should be simple and unpretentious and all people should be able to enter it in the easiest possible way and enjoy the space.
7. The most important thing is that space must be filled with laughter and waves of vitality and freshness.

Architecture location should serve the people. As shown in Figure 3, the subject of the design should be related to physical and aesthetic factors, and relaxing and beautiful design should encourage the citizens to attend. Attendance should be followed by attending hierarchies and there should be special architectural filters inside and outside and space should be away from extreme crowds. The rights of the place belong to the citizens and special applications should be responsible to provide services. Comfortable furnishings and design of green space will allow the audience to sit and to choose freely so that friendly atmosphere will be created between the citizens. Relevant and irrelevant spaces are distinguishable and visible and the access is the easiest and the closest option. Space construction should be transparent without corner waste and visible by the audience. This is an attempt to create security through the eyes of the other audiences of the place who are watching out space. The simplest situation and avoiding any luxuries are taken into account so that people with low economic classes never feel humiliated by being in such places. There are places for children to attend and play, green plants everywhere and dynamic and static fountains to create a sense of vitality and freshness in the designed environment. According to the components illustrated in diagram 3, in the architecture of a public place, a space with third place application is created which is converted from a mere public place to a place with social benefits.

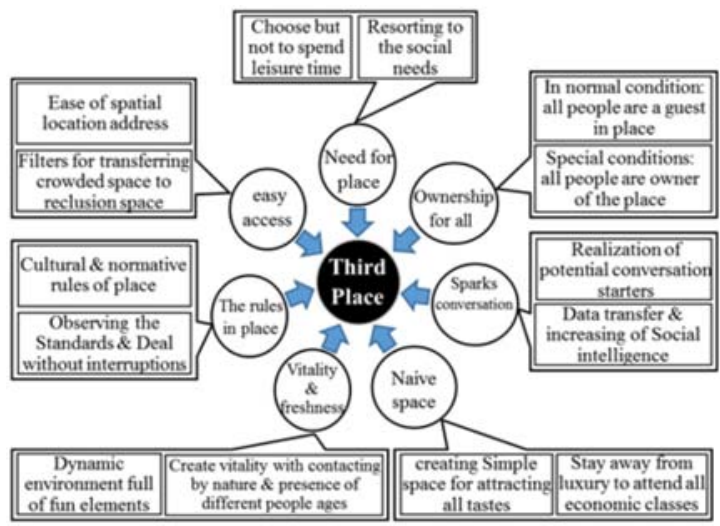

Diagram 3. Objectives and functions of third place in order to create architectural components

FORMATION OF THIRD PLACE IN ISLAMIC CIMES OF IRAN

The signs and documents remaining from the history of urbanism and architecture in Iran reflect attention to public places. Islam approaches in relation to "the community of believers and their contact and being aware of their religious brothers and sisters in all affairs" at the heart of Islamic city, displays the importance of collective places architecture [5]. City and urban growth and development heavily depend on social-intellectual life and architectural elements related to the issue so that it is possible to figure out the urban life and social relations in the light of Islamic 
thought through the history of the region [6]. The history of the area in terms of the urban development as well as architectural elements such as religious places, bazars, urban squares, and the dominant presence of Islamic thought in the course of the lives of people in the region are the evidence of social lifesocial relations with collective urbanization thought and the evidence of the architectural elements shaping and strengthening this issue [7]. This type of lifethought system "permeates the entire culture and customs of the region, and reveals the attention and the strength of social relations in the past urban relations of Iran" [8]. Approaches of Islam in the community of Islamic city have strengthened this issue more and more in life and architecture; Islam has considered the attention to social relations, religious community, and a single nation, "special attention to urban public centers such as bazar, central part of the city, and James' Mosque, where people can come together" very useful for the fittest religious community [9]. Strengthening social relations in Iran originates from the culture, customs, and ideas of Islamic values, which reflect such spaces for addressing the issue. "Islam believes that the continuity and foundation of its nation depend on maintaining the community and the unity of its members together" and the same intellectual tips in architecture have created a subject titled "delivering maximum public places in all urban applications" [10].

\section{THIRD PLACE IN HISTORIC URBAN SPACES OF IRAN}

Third place architecture in urban spaces of Iran is mainly formed based on intellectual and social needs, ethnocultural and characteristics, and religiousritual norms of each region Third place in urban areas of Iran includes squares, bazars, mosques, baths, houses and other spaces that have has several uses. In addition to the services that these places provided according to the type of their uses, they were places for deliberation, meeting, and greeting, respecting the elderly and other things that made people spend their time. Communication and coordination of this components have improved the third place in the cities of Iran to the favorite level and as the communication and coordination decrease, the concept of third place fades away too. In addition to the traffic and communication joint, the streets were the resorts for recreation and spending the leisure time and one of the most important examples is Chahar Bagh Street in Isfahan, table 1.

In this way, all places that made people come together in a way such as meeting the needs of citizens (bazar), urban reunion places (Jame' Mosque and city hall), pilgrimage sites (shrines and tombs of saints), urban

Table 1. Evaluation of four historical cities of Iran in terms of urban spaces that can be considered as a special definition of third place in the urban-historic development of cities in Iran with regard to their functions.

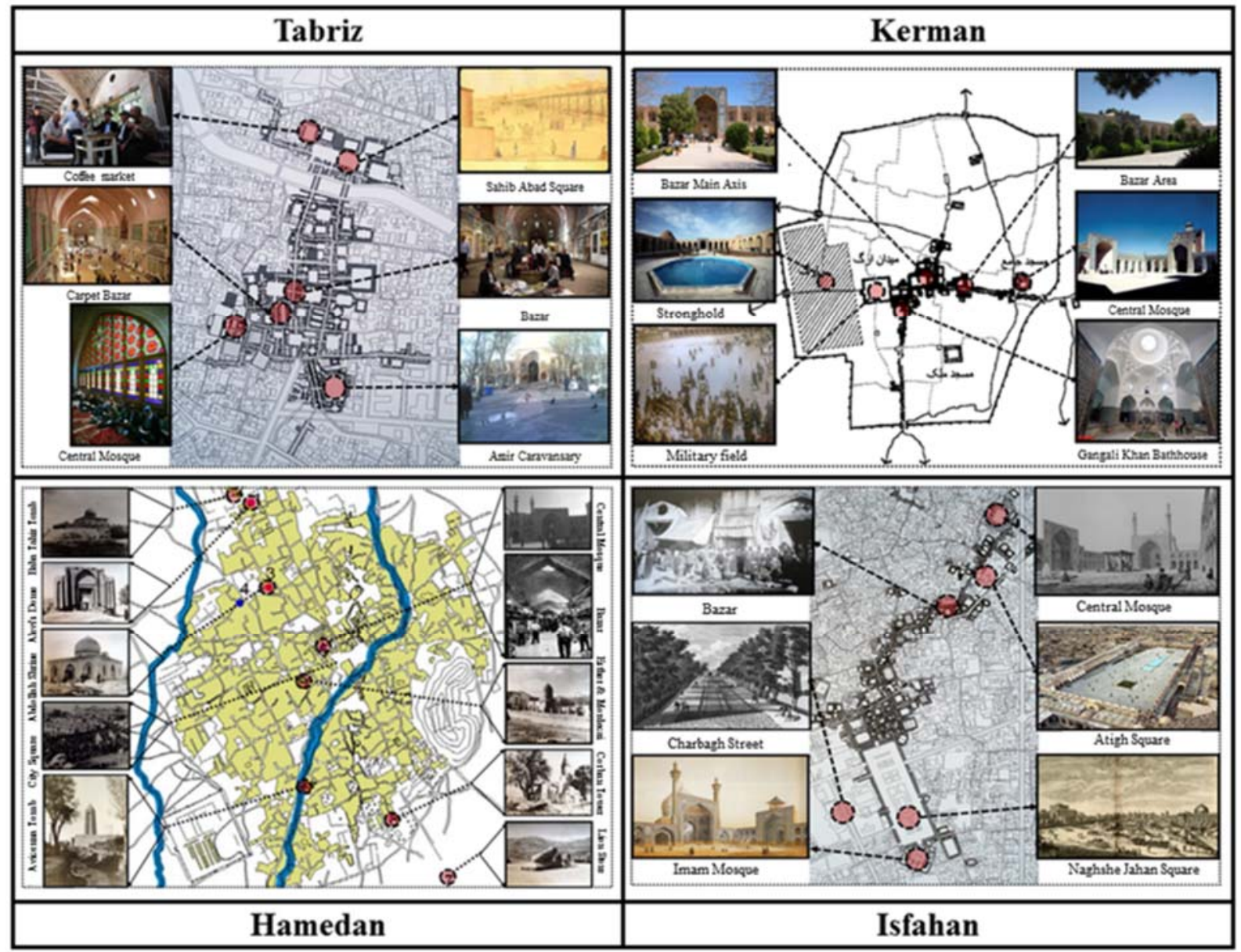


connecting nodes (centers of neighborhoods and squares), and service applications (baths), not only satisfied the main user needs, but also contained other elements of architecture and social affairs which means that in urban architecture of Iran each public space was intended to accomplish the third place in addition to its main application.

\section{HOUSING AND NEGHBORHOODS}

House and family in Iran are the first social issues in architectural design. According to Islamic thought, the issue of basic social thought of the most important social issues in urban planning and architecture. The first social events creating in this location and then spread in the other levels. This spread created due to the people's economic and social issues [11]. There's been a series regular and a network of good interaction between family started the field of social interaction, figure 1 . And the order is included these items, close neighbors, neighbors in the neighborhood, neighbors in other localities, social events in the community centers and then creating the events in the main square [12].

In fact, this square has both urban and social roles. All communications community centers and other urban elements are organized in the main squares. As was explained, this particular type of social interaction in residential areas started and expanded to major metropolitan areas that represent the Islam thought in the type of people communication for Islamic city. Islamic city is a vast city in the appearance, and integrated city in the back end.

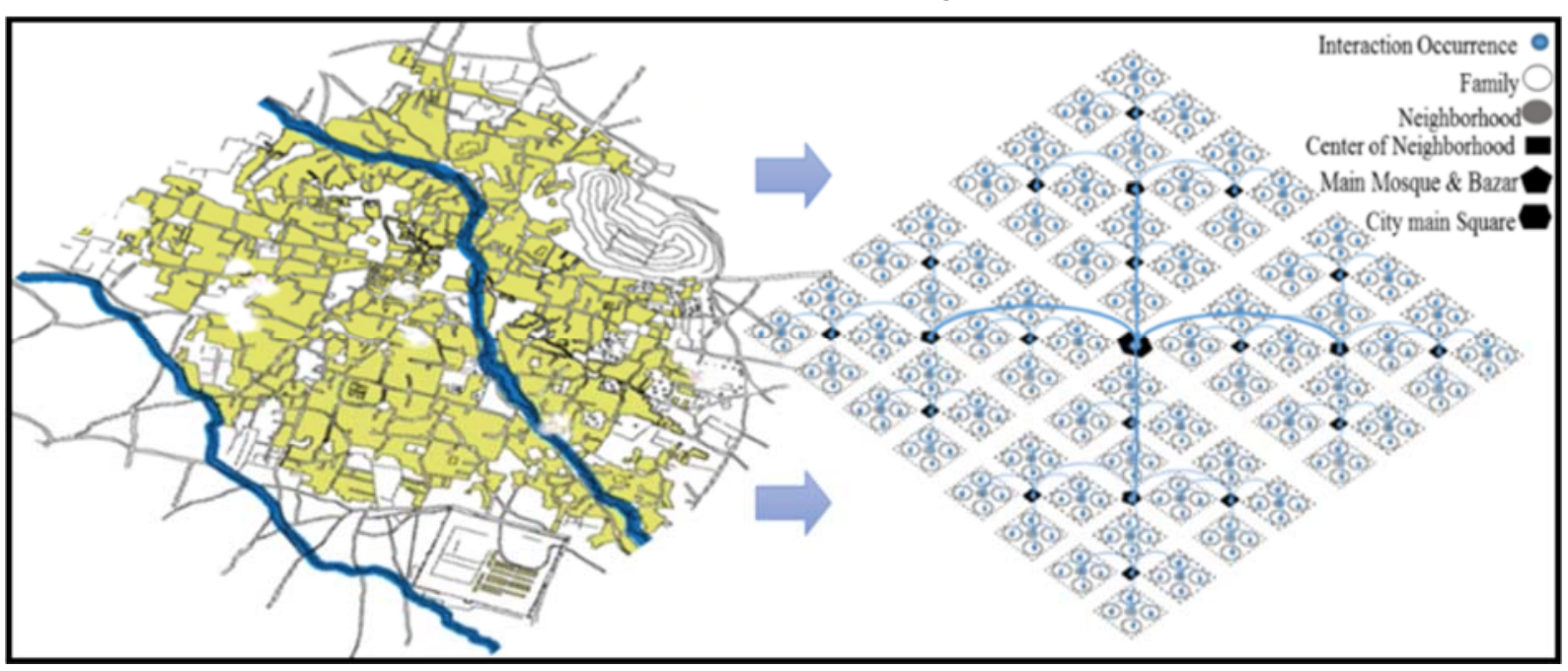

Figure 1. Social interactive network diagram: Homes and residential neighborhoods to the entire city of Hamadan Based on historical maps

The growth of social interaction in neighborhoods and districts centers as third places in the sphere of housing desired have created positive results in the cultural and social relations. Use this theme (social interaction \& third place) in architecture and urbanism enhances social relations and its expansion has been coupled with favorable results, for example, urban favorable decision, increasing people social decisions, reducing social vulnerability, establishment of social order, open services, enhance social relations in residential neighborhoods, increasing social security, integrated management of social organizations and in the final Social balance among citizens. This issue offers the specific definition of third place in Iran urbanism and architecture [13]. Taking into account the social needs of the citizens of houses and neighborhoods to the largest area of these happenings in the Islamic city is a basic solution in enhancing desirable social relationships. Architectural Social places in Islamic city actually is the third places in order to increase the social relations between people in the Islamic city. In this social architecture (Iranian third place Architecture) all events like social events, cultural events, and economic issues as well as created and grow.

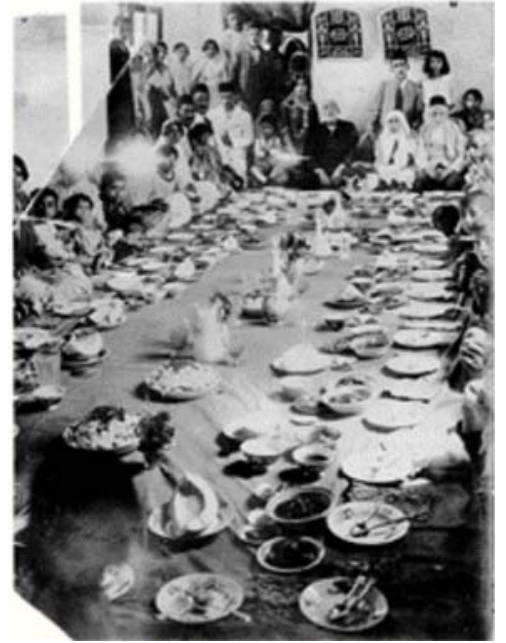

Figure 2. ceremony of Persian family in historical houses to interact together, source: http://axgig.com/ images/44230518100995969618.jpg

\section{URBAN WORSHIP PLACES AND MOSQUES}

They are considered as the third places in Iran that have open and closed spaces with special applications in their surroundings. The open spaces of these applications were designed with different 
functions and all these functions had some aspects of services.

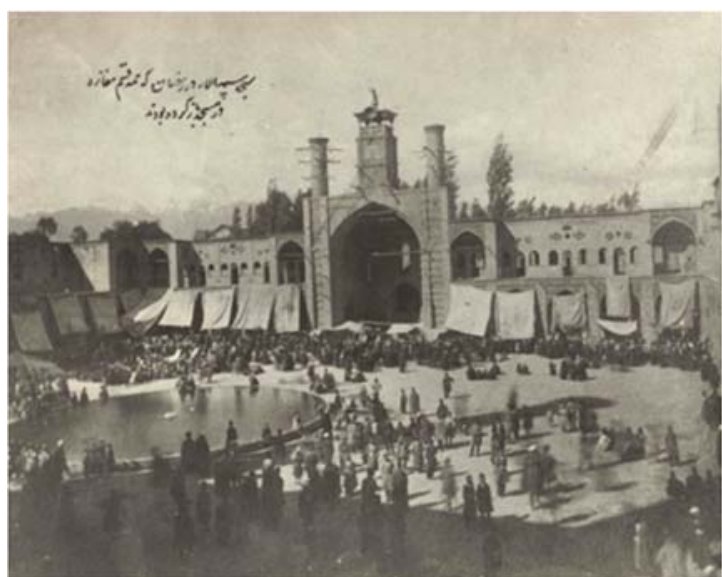

Figure 3. Ramadan public ceremony in the Tehran Sepahsalar Mosque, source: Golestan Palace

\section{URBAN SQUARES AND TRANSPORTATION NODES}

In addition to the joint communication application, they also have been in charge of other applications such as daily meetings, news and information exchange, informal education, experiences exchange, conducting national and religious ceremonies and charity. Islam tips have added the proper functioning of the fields in a way that it has recommended the believers to be aware of their religious brother's health and conditions and the squares were the most important centers for this matter. These matters made the citizens have a strong sense of belonging to the traditional squares of the cities. It is concluded that urban squares of Iran were among the best and a perfect kind of third place.

According to the results obtained in table 2, architectural components that can be stated about these places include the followings:

1. These places first satisfied the needs with regard to the type of their services [14].

2. Space architecture would be explained in such a way that a special space for the kind of place and additional place for people to stand up and sit down for some time were considered [15].

3. Respecting people especially the elderly and women has caused each public place to have special stands or furniture for people to sit and rest [16].

4. Public places had clearly defined space architecture, and special waste corners that reduced space transparency were eliminated [17].

5. Iranian architecture is highly dependent on the geometry and the principles of proportionality [17] and this point has been taken into account in the architecture of these places with regard to the large

Table 2. Display of architectural elements in Iran public places that have all the components of a third place

\begin{tabular}{|c|c|c|c|c|}
\hline \multicolumn{5}{|c|}{ Architectural Features of Collective Places in Iran } \\
\hline $\begin{array}{l}\text { Architectural Component } \\
\text { of Third Place }\end{array}$ & Source & Describe Component & Component & Row \\
\hline $\begin{array}{l}\text { landscape design and } \\
\text { environmental } \\
\text { beautification }\end{array}$ & $\begin{array}{l}\text { (Mehdinejad } \\
\text { \& Others, } \\
2013: 93 \text { ) }\end{array}$ & $\begin{array}{l}\text { with regard to hot and arid climate in most areas of Iran the use } \\
\text { of water and plants and trees is seriously felt in all architectural } \\
\text { spaces and in each place the powerful presence of nature has } \\
\text { been implemented as stylizing life conditions of the citizens }\end{array}$ & $\begin{array}{l}\text { Powerful } \\
\text { presence of } \\
\text { water and } \\
\text { nature }\end{array}$ & 1 \\
\hline service applications & $\begin{array}{l}\text { (Soltanzadeh, } \\
\text { 2013:27) }\end{array}$ & $\begin{array}{l}\text { the have met the needs with regard to the kind of the service } \\
\text { they provide }\end{array}$ & $\begin{array}{c}\text { Meeting } \\
\text { spatial needs }\end{array}$ & 2 \\
\hline creating wide spaces & $\begin{array}{l}\text { (Habibi \& } \\
\text { Pour } \\
\text { Mohammad, } \\
\text { 2014:9) }\end{array}$ & $\begin{array}{l}\text { Islam usual advice about creating and participating in } \\
\text { gatherings of the believers together in all areas of the faithful } \\
\text { society }\end{array}$ & $\begin{array}{l}\text { Including } \\
\text { permanent } \\
\text { public space }\end{array}$ & 3 \\
\hline $\begin{array}{l}\text { appropriate and } \\
\text { responsive furniture }\end{array}$ & $\begin{array}{l}\text { (Pimia, 2009: } \\
\text { 118) }\end{array}$ & $\begin{array}{l}\text { a special space for the kind of place and "additional place for } \\
\text { people to stand up and sit down for some time were considered }\end{array}$ & $\begin{array}{l}\text { Special space } \\
\text { furniture }\end{array}$ & 4 \\
\hline $\begin{array}{l}\text { architecture of versatile } \\
\text { and functional spaces }\end{array}$ & $\begin{array}{l}\text { (Mehdizadeh } \\
\text { \& Vali Beig. } \\
\text { 2011:21) }\end{array}$ & $\begin{array}{l}\text { clearly defined space architecture, and special waste corners } \\
\text { that reduced space transparency were eliminated }\end{array}$ & $\begin{array}{l}\text { Defined } \\
\text { space } \\
\text { construction }\end{array}$ & 5 \\
\hline $\begin{array}{l}\text { responsive architecture } \\
\text { in terms of design and } \\
\text { proportions }\end{array}$ & $\begin{array}{l}\text { (Hoijat \& } \\
\text { Maleki, 2012: } \\
\text { 11) }\end{array}$ & $\begin{array}{l}\text { Iranian architecture is highly dependent on the geometry and } \\
\text { the principles of proportionality }\end{array}$ & $\begin{array}{l}\text { Observing } \\
\text { geometry and } \\
\text { proportions }\end{array}$ & 6 \\
\hline $\begin{array}{l}\text { observing the standards } \\
\text { of the disabled people, } \\
\text { world travelers, mothers } \\
\text { and children }\end{array}$ & $\begin{array}{l}\text { (Zomorshedi, } \\
2008: 7)\end{array}$ & $\begin{array}{l}\text { respect for people, especially elders and women has caused the } \\
\text { presence of them to be considered with regard to their age- } \\
\text { gender hierarchy }\end{array}$ & $\begin{array}{l}\text { Honoring the } \\
\text { presence of } \\
\text { the elders and } \\
\text { women }\end{array}$ & 7 \\
\hline $\begin{array}{l}\text { interesting and beautiful } \\
\text { design to attract a variety } \\
\text { of tastes }\end{array}$ & $\begin{array}{l}\text { (Kafshchian } \\
\text { \& Others, } \\
\text { 2014:61) }\end{array}$ & $\begin{array}{l}\text { architectural decorations are very simple and in accordance } \\
\text { with Islamic tips in relation to the kind of righteous decorations }\end{array}$ & $\begin{array}{l}\text { Space and } \\
\text { decorative } \\
\text { simplicity }\end{array}$ & 8 \\
\hline \multicolumn{3}{|c|}{$\begin{array}{l}\text { Components and features of third place in the cities of Iran for designing the architecture of } \\
\text { communal spaces }\end{array}$} & \multicolumn{2}{|c|}{ As a Result } \\
\hline
\end{tabular}


number of their visitors and in general they have had appropriate architectural form and beautiful space despite their simplicity.

6. Architectural decorations have been implemented very simple and in accordance with the Islam advice in relation to the righteous decorations [18].

7. With regard to the prominent arid climate in most areas of Iran, the use of water and plants and trees is heavily felt in all architectural spaces and in each place the powerful presence of nature can be seen as stylizing life conditions of the citizens [19].

8. According to the advice of Islam in relation to the presence of elders in all areas of people's lives and a special focus on the love of children and women and putting valuable stands in space [20]. The hierarchical places of architecture will seek to resolve any problems of their presence. It can be concluded that public places architecture in Iran, according to table 2, is intensively related to the advice and principles of Islam in relation to the good life, and extreme attention of architecture to the urban community of Iran and Islam thought which are strongly related to each other can be observed in such places.

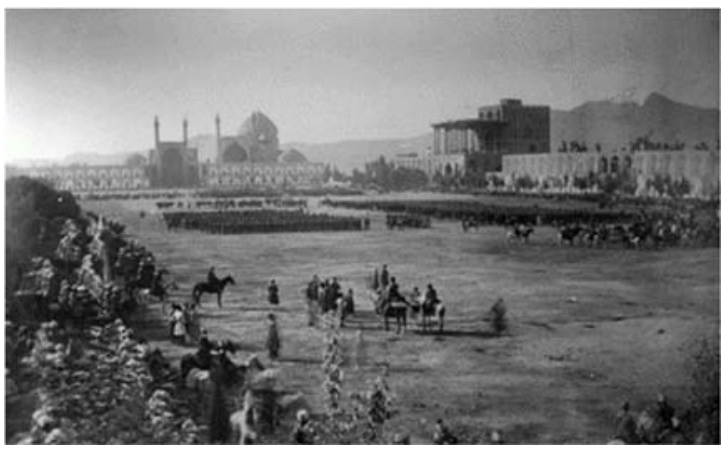

Figure 4. Isfahan Naqsh-e Jahan Square in Qajar Era, source: Institute for Iranian Contemporary Historical Studies

According to the Islamic thought and the type of current culture, third place in the past urbanism has mainly focused on the citizen's needs in relation to the individual's relationship with each other. Accordingly, in positioning and placement of urban spaces, the third place has been more important than the first and second places. This mater has also been of great importance in both Islamic thoughts and culture. In the cities of Iran, according to table 1, houses have been built around special places such as Jame' Mosque, bazar, holy shrines, and city halls with organic-like arrangements which reveal the role of the third place in this regard as well as social interactions and its recognition in urban architecture of Iran as one of the most important foundations of urban design and development.

\section{CONCLUSION}

Several factors and components influenced the architecture of urban public places in Iran. This will appear in each climate and region with regard to various biological differences. Therefore, in response to the research question that what are the features of pre-modern third space in Iranian cities and whether the features are in accordance with the definition of third place the findings of the research indicate that there is a deep relationship between the concept of third place in the architecture of Iran cities and principles and tips of Islam as well as ethnocultural situation. These subjects have blended with other components and have made the architecture of collective places which have an application with social flexibility from the architectural point of view, the one that not only provides services with place application but also responds to social issues of the city. The components of the urban architecture are being dressed with ethnic, cultural, and religious points and objectives of Iran show a different figure of the third place. This point has been strongly focused in a premodern era when the attention to these issues was the foundation of urban spaces formation so that in a more literal term, it has made these spaces more friendly and familiar, for the use of Iranian users with regard to the type of place and location. The most important point is the great effect of Islamic tips and principles as well as ethnocultural traditions and customs in communal places. Most architectural places in Iran, where the micro and macro presence of the citizens can be seen, in addition to providing locationspecific user services, play the role of the third place to some extent, whether low or high. This point has greatly increased within the community of the believers with the emphases and the teachings of Islam in relation to appropriate communication with other members of the society under the title of good social relations. This matter is presented differently in non-Iranian patterns and each user plays his own rule according to the urbanization order. The user who plays the role of collective place in social relations or the third place can fully play the role and should be placed in the city in a separate way.

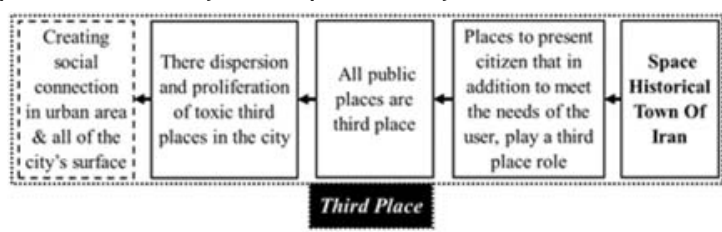

Diagram 5. Definition and type of third place in the historicalurban space of Iran

As a result, the third place in the urban architecture of Iran is scattered and can be seen in all places and applications. Proper use of nature and landscape, meeting the early needs of people in place, creation of urban furniture, applied decoration and geometry, observing the standards of the presences of disabled people and respecting the rights of women and mothers in space are among the components that prepare the space for the social interactions of the space audiences. While in the urban architecture of non-Iranian patterns the third place is located in special areas according to urban calculations and measurement and most of the social interactions and 
relations should occur in that particular area, in Iranian pattern each opportunity and space have been seized for enhancing, strengthening, and continuing good social relations.

\section{REFRENCES}

[1] A. N. Ebrahimi, F. P. Rahimian, and M. S. Loron, "Impacts of Urban Passages on Formation of Iranian Bazaars: Case Study of the Historic Bazaar of Tabriz," Archnet-IJAR, vol. 7, no. 2, pp. 58-69, 2013.

[2] L. W. Jeffres, M. F. Casey, G. Jian, and C. C. Bracken, "The Impact of Third Places on Community Quality of Life," Appl. Res. Qual. Life, vol. 4, pp. 333-345, 2009.

[3] E. Y. Bentley, P. Morin, S. McGin, and G. Smith, Responsive environment. Translate by Mostafa Behzadfar. Tehran: University of Science \& Technology, 2003.

[4] C. Peterson, Pursuing the Good Life. New York: Oxford University press, 2013.

[5] A. J. Amoli, The Key of Life. Qom: Esra Press, 2013.

[6] W. Hintes, Elam City of Princess. Translated by Parviz Rajabi. Tehran: Mahi Press, 2009.

[7] D. M. Mikhailovich, History of Ancient Iran. Translate by Rouhi Arbab. Tehran: Scientific \& Cultural Press, 2003.

[8] J. Cameron, Iran At the Dawn of History. Translated by Hassan Anousheh. Tehran: Central University Press, 2000.

[9] S. M. Habibi, From Old Town to Town. Tehran: University of Tehran Press, 2007.

[10] M. Koleini, Usul al-Kafi, Vol.4. Qom: Osveh
Press, 2009.

[11] F. Rohafza, "Compare the Family in Islam \& the West," Third Congress of Strategic Ideas About Wife \& Family, pp. 1235-1255, 2009.

[12] A. N. Ebrahimi and A. H. Farshchian, "Third Place in Contemporary Architectural \& Urbanism of Iran," GAU J. Soc. Appl. Sci., vol. 6, no. 10, 2014.

[13] O. S. Fakher, Social Trust \& Community Relations. Tehran: Thought \& Culture Press, 2010.

[14] H. Soltanzadeh, The Historical Context of Urban Spaces. Tehran: Cultural Research Press, 2014.

[15] M. K. Pirnia, Iranian Architecture, Tehran. Soroush Press, 2008.

[16] H. Zomorshedi, "Iranian Architecture Arts," Art Learning Magazine, pp. 4-13, 2009.

[17] S. Mehdizadeh, F. Tehrani, and N. Valibeig, "The Use of Triangles Norm in Math and Geometry Implementation and Enforcement of Traditional Iranian Architecture," Architecture \& Restoration of Iran Magazine, pp. 15-26, 2011.

[18] A. K. Moghadam, A. Mansouri, and R. Shamsizadeh, "Check Decorations Traditional Architecture from the Perspective of Graffiti," Visual Arts Magazine, pp. 57-64, 2014.

[19] J. M. Nejad, S. Sabouri, and E. Damavandi, "Architectural Design With an Emphasis on the Interaction of Beauty and Function in Nature," City Identity Magazine, pp. 59-66, 2012.

[20] S. M. Habibi and M. R. Navidpour, "Public Space \& Public Life in Historical City," City Identity Magazine, pp. 5-14, 2013. 